\title{
Nephrotoxicity of polymyxin B: \\ experimental study in cells and implications for nursing practice*
}

\author{
NEFROTOXICIDADE DA POLIMIXINA B: ESTUDO EXPERIMENTAL EM CÉLULAS E \\ IMPLICAÇÕES PARA A PRÁTICA DE ENFERMAGEM
}

\section{LA NEFROTOXICIDAD DE POLIMIXINA B: ESTUDIO EXPERIMENTAL EN LAS CÉLULAS Y IMPLICACIONES PARA LA PRÁCTICA DE ENFERMERÍA}

\section{Luciana Barros de Moura Neiva1, Fernanda Teixeira Borges ${ }^{2}$, Mirian Watanabe ${ }^{1}$, Edson de Andrade Pessoa ${ }^{3}$, Dulce Aparecida Barbosa ${ }^{4}$, Maria de Fatima Fernandes Vattimo ${ }^{5}$}

\begin{abstract}
The aim of the study was to characterize the cell damage mechanisms involved in the pathophysiology of cytotoxicity of polymyxin $B$ in proximal tubular cells (LLC - PK1) and discuss about the nurses interventions to identify at risk patients and consider prevention or treatment of nephrotoxicity acute kidney injury. This is a quantitative experimental in vitro study, in which the cells were exposed to $375 \mu \mathrm{M}$ polymyxin B sulfate concentration. Cell viability was determined by exclusion of fluorescent dyes and morphological method with visualization of apoptotic bodies for fluorescence microscopy. Cells exposed to polymyxin B showed reduced viability, increased number of apoptotic cells and a higher concentration of the enzyme lactate dehydrogenase. The administration of polymyxin B in vitro showed the need for actions to minimize adverse effects such as nephrotoxicity.
\end{abstract}

\section{RESUMO}

O objetivo do estudo foi caracterizar os mecanismos de lesão celular envolvidos na fisiopatologia da citotoxicidade da polimixina B em células tubulares proximais (LLC-PK1) e discutir as proposições de intervenção do enfermeiro para identificar os pacientes de risco e considerar a prevenção ou o tratamento para lesão renal nefrotóxica. Estudo experimental in vitro, onde as células foram expostas ao sulfato de polimixina B. A viabilidade celular foi determinada pela exclusão dos corantes fluorescentes e o método morfológico com visualização de corpos apoptóticos à microscopia de fluorescência. As células expostas à polimixina $\mathrm{B}$ apresentaram redução de viabilidade, aumento do número de células em apoptose e maior concentração da enzima desidrogenase láctea. A administração de polimixina $B$ in vitro demonstrou a necessidade de ações na prática clínica para minimizar os efeitos adversos como a nefrotoxicidade.

\author{
DESCRITORES \\ Polimixina B \\ Antibacterianos \\ Lesão renal aguda \\ Células LLC-PK1 \\ Cuidados de enfermagem
}

\section{RESUMEN}

El objetivo del estudio fue caracterizar los mecanismos de daño celular implicado en la fisiopatología de la citotoxicidad de la polimixina $B$ en las células tubulares proximales (LLC-PK1) y discutir las propuestas de intervención de enfermería para identificar a los pacientes de riesgo y considerar la prevención o el tratamiento de la lesión renal aguda nefrotóxica. Corresponde a un estudio experimental cuantitativo in vitro, en el cual las células fueron expuestas a sulfato de polimixina B. La viabilidad celular se determinó por exclusión de los colorantes fluorescentes y el método morfológico con la visualización de cuerpos apoptóticos a la microscopía de fluorescencia. Las células expuestas a polimixina B demostraron reducción de la viabilidad, aumento de células apoptóticas y mayor concentración de la enzima lactato deshidrogenasa. La administración de polimixina $\mathrm{B}$ in vitro demostró la necesidad de realizar acciones en la práctica clínica para minimizar los efectos adversos como la nefrotoxicidad.

\author{
DESCRIPTORES \\ Polimixina B \\ Antibacterianos \\ Lesión renal aguda \\ Células LLC-PK1 \\ Atención de enfermería
}

\footnotetext{
* Extracted from the thesis "Toxicity of polymyxin B in LLC-PK1 cells and the heme oxygenase-1 enzyme", School of Nursing, Universidade de São Paulo, 2008. ${ }^{1} \mathrm{PhD}$ at the School of Nursing, Universidade de São Paulo, São Paulo, SP, Brazil. ${ }^{2}$ PhD at the Department of Nephrology, Universidade Federal de São Paulo, São Paulo, SP, Brazil ${ }^{3}$ MSc at the Department of Nephrology, Universidade Federal de São Paulo, São Paulo, SP, Brazil. ${ }^{4}$ Associate Professor, Department of Clinical and Surgical Nursing, Escola Paulista de Enfermagem, Universidade Federal de São Paulo, São Paulo, SP, Brazil. ${ }^{5}$ Associate Professor, Department of Medical-Surgical Nursing, School of Nursing, Universidade de São Paulo, São Paulo, SP, Brazil. nephron@usp.br
} 


\section{INTRODUCTION}

The hospital acute kidney injury (AKI) is of multifactorial causes, and recent epidemiological studies link the nephrotoxic drugs with $19-25 \%$ of cases of $\mathrm{AKI}^{(1-2)}$. The nephrotoxins are the second most frequent cause ${ }^{(2)}$. Antimicrobial agents such as aminoglycosides, amphotericin $B$, acyclovir, pentamidine, foscarnet, and chemotherapeutic agents such as ifosfamide and cisplatin are toxic to the renal tubule ${ }^{(2-3)}$. Among these frequently used substances in patients in intensive care units, are the polymyxins, which have a great nephrotoxic potential.

The polymyxin B (PmB) provides an effective and rapid bactericidal activity for a variety of Gram-negative bacteria such as Escherichia coli, Klebsiella pneumoniae and Pseudomonas aeruginosa. It is quite effective in the treatment of sepsis, meningitis, urinary tract infection, skin and eye infections.

Prior to the appearance of new aminoglycosides, penicillins and cephalosporins, the PmB was the drug of choice for the treatment of Pseudomonas aeruginosa. It is currently reserved for the treatment of multiresistant bacteria to other antibiotics ${ }^{(4-6)}$.

PmB sulfate or Aerosporin, is a cyclic cationic decapeptide with active surface that fits into the bacterial cell membrane, settling to lipid $A$, rendering ineffective its osmotic barrier, which leads to loss of cell contents (amino acids, purines, pyrimidines and dilution of substrates for phenomena of synthesis) and bacterial cell death ${ }^{(4,6)}$.

PmB is excreted mainly by the kidneys, and high concentrations of the drug in the body promote disruption of plasma membrane and increased permeability to cations, which results in swelling and lysis. This process involves a mechanism of oxidative damage, alteration in mitochondrial apoptosis and necrosis of proximal tubule cells ${ }^{(2,7)}$, culminating in renal dysfunction, characterized by imbalance of water and electrolytes and reduced excretion of nitrogenous products of metabolism such as urea and creatinine.

It is noteworthy that the successful prevention of AKI requires knowledge of the pathogenic mechanisms involved, the identification of individual risk factors and early measures associated with surveillance and intervention. It is inserted in this context the stimulus to models of research about the cellular changes involved in functional disorder precipitated by nephrotoxins.

This study, supported by experimental research, can bring important contribution to the clinical area and allow early clinical reasoning, from the findings in studies with cells that guide the prevention or early treatment of patients with AKI. The objectives of the study are to characterize the mechanisms of cell damage involved in the pathophysiology of cytotoxicity of PmB in proximal tubular cells (LLC-PK1), discuss the intervention proposals of nurses to identify patients at risk and to consider prevention or treatment for nephrotoxic AKI.

\section{METHOD}

Experimental in vitro study carried out in the Laboratory of Experimental Animal Model of the School of Nursing of the Universidade de São Paulo (LEMA - EEUSP) and the Laboratory of Cellular and Molecular Biology of the Nephrology Department of the Universidade Federal de São Paulo (UNIFESP).

Immortalized LLC-PK1 cells, a proximal tubular epithelial pig line, obtained from the American Type Culture Collection (ATCC) were used. These cells were extracted from the Hampshire pig and have morphological characteristics of renal epithelium as apical microvilli, tight junctions and basolateral membrane.

The LLC-PK1 were grown in culture bottles of $25 \mathrm{~cm}^{2}$, $75 \mathrm{~cm}^{2}$ or multiwell six-well plates, according to the experimental protocol in Dulbecco's Modified Eagle's Medium (DMEM), supplemented with fetal bovine serum (FBS $5 \% \mathrm{v}$ / v), $\mathrm{NaHCO}_{3} 2.0 \mathrm{~g} / \mathrm{L}$, HEPES $2.6 \mathrm{~g} / \mathrm{L}$, penicillin 10,000 IU/L, streptomycin $50 \mathrm{mg} / \mathrm{L}$ and neomycin $100 \mathrm{mg} / \mathrm{L}$ and kept in the incubator at $37^{\circ} \mathrm{C}$ with $95 \%$ air and $5 \% \mathrm{CO}_{2}$. Upon reaching $80 \%$ confluence, cells were detached from the flask by trypsinization and the trypsin activity neutralized with DMEM containing FBS. Cells were used for maintenance of the cultures or for conducting the experimental protocols, with each protocol repeated at least four times. Cell stocks were frozen at passage seven for maintaining uniformity in the experiments.

LLC-PK1 cells were divided in two groups, as follows: Control (CTL), with cells maintained in DMEM 5\% and PmB with cells exposed to concentration of $375 \mu \mathrm{M}$ of sulfate of PmB.

Cell viability was determined by exclusion of fluorescent dyes acridine orange and ethidium bromide (Sig$\mathrm{ma})^{(8)}$. In order to read viability were used only $10 \mathrm{~mL}$ of the suspension of trypsinized cells that were mixed with $0.3 \mathrm{~mL}$ of the solution of acridine orange dye and ethidium bromide $(100 \mathrm{mg} / \mathrm{ml})$ in a ratio $\mathrm{v}: \mathrm{v}(1: 1)$. The method of viable cell count is based on the selective uptake of the mentioned dyes, which is dependent on the integrity of the plasma membrane. Ethidium bromide passes through the intact membrane, by binding to cellular DNA and emitting green fluorescence $(460 \mathrm{~nm}$ excitation and $650 \mathrm{~nm}$ emission) indicating cells are viable. The acridine orange stains RNA but it does not pass through intact membrane, is captured only by cells whose membrane is damaged and fluoresces orange-red $(510 \mathrm{~nm}$ excitation and $595 \mathrm{~nm}$ emission), showing which cells are not viable. At the end, at least 200 cells were counted for each representative group through a fluorescence microscope (magnification 40x and 200). The results were expressed as percentage of viable cells.
Nephrotoxicity of polymyxin B: experimental study in cells and implications for nursing practice Neiva LBM, Borges FT, Watanabe M, Pessoa EA, Barbosa DA, Vattimo MFF 
The assessment of apoptosis is the morphological method, quantitative Hoechst 33342 [Bisbenzimide HOE 33342 (2'-[4-etoxifenil]-5-[4-metil-1-piperazinil]-2,5'-bi$1 \mathrm{H}$-benzimidazol tricloridrato)], which is a specific dye for adenine-thymine. This dye is easily absorbed by the cell, staining the DNA, chromosomes and the nucleus, enabling the visualization of apoptotic bodies for fluorescence microscopy in intense blue coloration.

For evaluation of apoptosis it was prepared a solution 100mg/mL Hoescht 33342 dye in PBS (Phosphatebuffered saline). The cells were subjected to the same described preparation for viability assessment, to obtain the cell pellet. On the blade $5 \mathrm{~mL}$ was pipetted on the slide of Hoechst 33342 added to $5 \mathrm{~mL}$ of the cell suspension. The blade was stored for 10 minutes at room temperature and in the absence of light for chromatin staining ${ }^{(8)}$. Then the procedure was the count of 100 to 200 cells for each group. Results were expressed as percentage of apoptotic cells compared to total cells.

The degree of cell damage was assessed by measurement of lactate dehydrogenase (LDH) in the culture medium and cell. The release of LDH enzyme that catalyzes the reduction of pyruvate to lactate was measured in the cells and culture medium. The relationship between the activity of extracellular LDH (culture medium) and total activity (intracellular and culture medium) established the degree of cell damage. The culture medium was aspirated and transferred to a conical tube, centrifuged

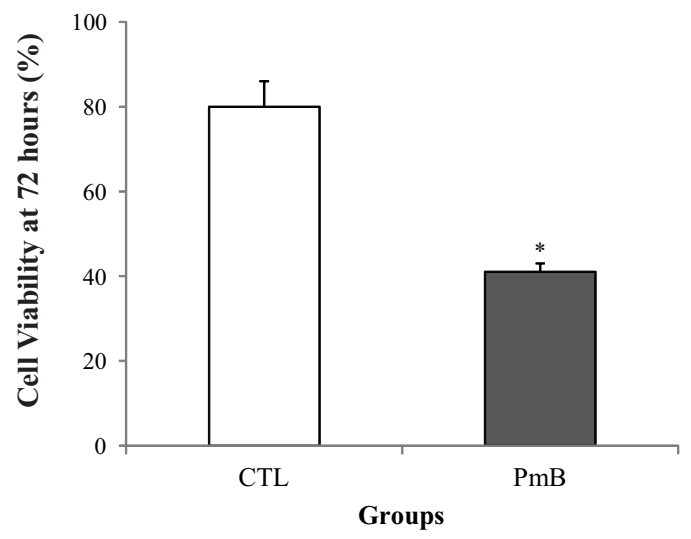

at $2000 \mathrm{rpm}$ for 4 minutes and the supernatant was removed for reading. The cells were washed with PBS twice and lysed with the detergent Triton X-100 1\% for the concentration dosage of cellular LDH. The kinetic method was used, in which the conversion of pyruvate to lactate was observed for determining the amount of $\mathrm{LDH}$. This reaction was performed with the LDH Kit Liquiform ${ }^{\circledR}$ and the reading of the Bio - 200. The results were presented as percentage of damaged cells. For the calculation, the following formula was used: [culture medium/(culture medium + cell number)] $\times 100 \%{ }^{(8)}$.

\section{Statistical analysis}

The applied statistical methodology consisted of analysis of variance - ANOVA. When differences were detected, there were multiple comparisons by using the Bonferroni test and Tukey test. The descriptive statistics with $p<0.05$ were considered significant. Data were defined as mean \pm standard error and are shown in tables.

\section{RESULTS}

Figure 1 demonstrates a significant reduction in cell viability at the exposure dose of $375 \mu \mathrm{M}$ of $\mathrm{PmB}$, which reflects its toxicity (CTL: $81 \pm 6 \%$ versus $\mathrm{PmB}$ : $41 \pm 2 \%$; $\mathrm{p}<0.05)$. Inversely, this dose increased the number of apoptotic cells at 72 hours (CTL: $9 \pm 2 \%$ versus PmB: $36 \pm 4 \% ; p<0.05$ )

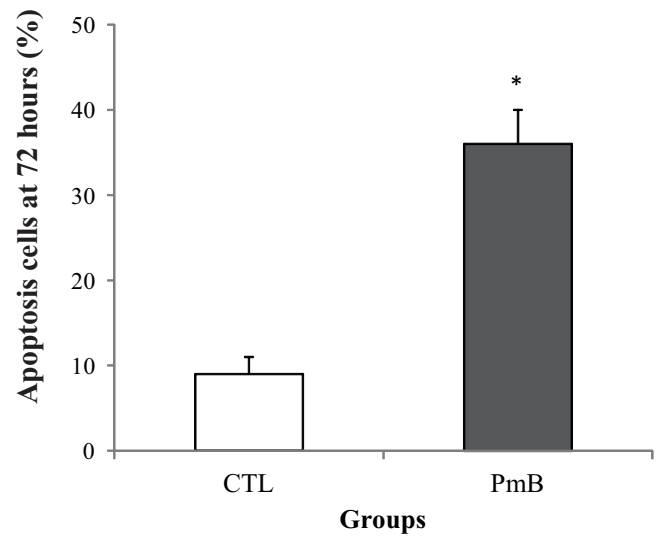

CTL - Control, PmB - Polymyxin B. ${ }^{*} \mathrm{p}<0.05$ versus Control Figure 1 - Viability and apoptosis of LLC-PK1 cells.

Table 1 shows the results of LDH release in LLC-PK1 cells. Starting treatment with a dose of $375 \mu \mathrm{M}$ PmB there was significant increase in $\mathrm{LDH}$ release, compared to the control group $(p<0.05)$.

Table 1 - LDH release in LLC-PK1 cells.

\begin{tabular}{ccc}
\hline Groups & N & LDH (\%) \\
\hline Control & 8 & $1.77 \pm 0.17$ \\
Polymyxin B & 8 & $22.66 \pm 1.77^{*}$ \\
\hline${ }^{*} \mathrm{p}<0,05$ versus Control
\end{tabular}

${ }^{*} p<0,05$ versus Control.

\section{DISCUSSION}

In vitro models that simulate PmB toxicity in renal cells are not common. Despite its known nephrotoxic potential, intra-hospital application has been frequent due to the presence of multiresistant microorganisms.

This study demonstrated that LLC-PK1 cells exposed to $375 \mu \mathrm{M}$ PmB showed reduction in cell viability. In renal cells, this cytotoxic dose of PmB may also determine the mechanism of renal tubular cell death. 
In response to cytotoxic events to the kidney, it is possible to recognize four basic directions: the cells may enter necrosis or apoptosis; can replicate and divide or may be indifferent to stress ${ }^{(9)}$.

In clinical practice, AKI is conventionally known as acute tubular necrosis (ATN). Experimental studies have shown that the straight portion of the proximal tubule ( $\mathrm{S} 3$ segment) is the most vulnerable to ischemic or nephrotoxic injury. These tubular cells lose their brush border and undergo extensive cell necrosis. Despite the frequent use of the term necrosis, apoptosis, which is another mechanism of cell death, is also present in ischemic and nephrotoxic injuries ${ }^{(2)}$.

It is noteworthy that the cells exposed to PmB showed an increase in the number of cells undergoing apoptosis. The cell necrosis was observed indirectly through the release of $\mathrm{LDH}$ into the extracellular medium. The LDH, a cytosolic enzyme, is released by rupturing the cell membrane, indicating cell death by necrosis. Apoptosis is a rapid, synchronized process that culminates in the nuclear and cellular fragmentation in apoptotic vesicles. Unlike necrosis, there is no release of cellular contents into the extracellular medium, characterized by the absence of inflammation around the dead cell. Necrosis is an irreversible degenerative phenomenon, caused by intense aggression, i.e., high doses of nephrotoxic drugs such as PmB, chemotherapy or iodinated contrast media, explaining that the severity of aggression seems to be the determining factor in the mechanism of cell death.

The onset of AKI secondary to the use of PmB often occurs a few days after the start of drug therapy in hospitalized patients. The toxicity of this substance is dose and time dependent, considering it is primarily excreted by the kidneys. An in vitro study demonstrated PmB injury in LLC-PK1 cells with the evolution of time and dose ${ }^{(10)}$.

This study used the in vitro model of transposition of clinical scenarios for the lab bench, in an attempt to isolate non-modifiable factors in humans, but that in the cellular medium can be differentiated and identified. A current approach allows the introduction of the three phases of translational research, the ' 3 Bs' (Bench, Bedside and Back again), a dynamic and feedback process ${ }^{(11)}$.

The first pillar - bench - is formed by the basic research in vivo or in vitro, which is the basis for the exercise of practical reasoning and establishment of new clinical guidelines ${ }^{(11-12)}$. In other words, its results applied to nursing practice can determine care activities that are supported by the pharmacological knowledge of PmB and the pathophysiology of toxic AKI, characterizing the transposition of basic experimental research to healthcare practice ${ }^{(13)}$. The second pillar - bedside - encompasses studies that evaluate the effectiveness, acceptability and cost/benefit of interventions of clinical sciences ${ }^{(11-12)}$, exemplified by randomized studies that evaluate the effectiveness of preventive measures undertaken in patients who have risk factors for AKI during the administration of nephrotoxic drugs ${ }^{(14-15)}$. And the last pillar - back again - adds the necessary information to convert treatments and prevention strategies in foundation for evidence-based health policies ${ }^{(11,13)}$.

\section{Implications for practice}

The nephrotoxic AKI is an iatrogenic disease caused by the administration of drugs or contrasts for image diagnosis in patients with risk factors or situations ${ }^{(16-17)}$. Clinical features include oliguria or anuria, elevation of serum creatinine and electrolyte disturbances ${ }^{(17)}$. The incidence of AKI may be associated with periods of prolonged hospitalization resulting in increased morbidity and mortality and, consequently, increase of hospital costs of these patients ${ }^{(18)}$.

In this context, stands out the role of nurses in monitoring, analysis and interpretation of laboratory exams and identification of risk factors associated with the development of AKI. The efficiency of nursing care is determined by means of early identification of $\mathrm{AKI}$, or rather the recognition of related factors or defining characteristics for PmB nephrotoxicity that allow to establish the first guidelines ${ }^{(19-20)}$.

The first strategies are the correct completion of the nursing history and the physical examination to identify risk factors associated with nephrotoxic drug-induced AKI. The main feature of the AKI is the reduction of glomerular filtration rate, which results in accumulation of nitrogenous products - urea and serum creatinine-a medical condition called azotemia $^{(16)}$. Patients with minimal reduction in filtration rate have risk factors for $\mathrm{AKI}^{(7)}$.

Nurses should also consider the continued use of medications and especially those with nephrotoxic potential. A classic example are the non-steroidal anti-inflammatory drugs and the inhibitors of angiotensin converting enzyme (ACE), which reduce renal perfusion and favor the mechanism of renal injury ${ }^{(21)}$. The same perception and attention should be given to the indiscriminate and more recent use of vitamin supplements and herbal medications, because many patients do not consider this category as drugs and are unaware of their contribution to the development of $\mathrm{AKI}^{(16)}$.

Toxic AKI involves numerous intrinsic factors, some nonmodifiable, such as high age, gender, hypertension, chronic renal failure, congestive heart failure, multiple myeloma and modifiable factors such as dehydration, medication dosage, hypotension, concomitant use of nephrotoxic drugs, shock and $\operatorname{sepsis}^{(7,14,21)}$.

The preparation of a plan of care for patients in use of nephrotoxic drugs involves mainly the action of nurses in modifiable factors. During hospitalization of patients, episodes of hypotension should be monitored and avoided, since the reduction of blood perfusion can lead to kidney damage. The volemic status of the patient should also be carefully controlled by means of urinary flow. Hypovolemia is directly associated with toxic AKI ${ }^{(16,21-22)}$.

Another item to consider is the patient's prescription, where various pharmacological agents are administered for the treatment of various pathologies. The
Nephrotoxicity of polymyxin B: experimental study in cells and implications for nursing practice Neiva LBM, Borges FT, Watanabe M, Pessoa EA, Barbosa DA, Vattimo MFF 
adjustment of the drug dose in relation to body weight and the ability of excretion should be done especially during the administration of nephrotoxic drugs. The adjustment in the dose of the drug is needed to ensure that the correct therapeutic range is reached and the incorrect dosage or maintenance of high doses increases the incidence of $\mathrm{AKI}^{(16,23)}$.

During the administration of $\mathrm{PmB}$ it is important that the nurses acknowledge the major risk factors associated with patients and apply all the available mechanisms of renal protection for maintaining the volume, care in the use of other nephrotoxic medications and close monitoring of renal function, with laboratory control of creatinine, urea, electrolytes and urine flow ${ }^{(16)}$.

\section{CONCLUSION}

The cytotoxicity of PmB was determined by reduction of viability, increase of cells in apoptosis and release of the lactate dehydrogenase enzyme, signaling to cell damage by necrosis. The administration of PmB involves actions to minimize adverse effects, in which the main focus is nephrotoxicity for identifying risks and the mechanism of renal protection.

\section{REFERENCES}

1. Uchino S, Kellum JA, Bellomo R, Doig GS, Morimatsu H, Morgera $S$, et al. Acute renal failure in critically ill patients: a multinational, multicenter study. JAMA. 2005;294(7):813-8.

2. Pannu N, Nadim MK. An overview of drug-induced acute kidney injury. Crit Care Med. 2008;36 Suppl 4:S216-23.

3. aber SS, Pasko DA. The epidemiology of drug induced disorders: the kidney. Expert Opin Drug Saf. 2008;7(6):679-90.

4. Falagus ME, Kasiakou SK. Toxicity of polymyxins: a systemic review of the evidence from old and recent studies. Crit Care. 2006;10(1):R27.

5. Landman D, Georgescu C, Martin DA, Quale J. Polymyxins revisted. Clin Microbiol Rev. 2008;21(3):449-65.

6. Chan-Tompkins NH. Multidrug-resistent gram-negative infections. Bringing back the old. Crit Care Nurs Q. 2011;34(2):87-100.

7. Perazella MA. Renal vulnerability to drug toxicity. Clin J Am Soc Nephrol. 2009; 4(7):1275-83.

8. Pessoa EA, Convento MB, Silva RG, Oliveira AS, Borges FT, Schor N. Gentamicin-induced preconditioning of proximal tubular LLCPK1 cells stimulates nitric oxide production but not the synthesis of heat shock protein. Braz J Med Biol Res. 2009; 42(7):614-20.

9. Liang M, Knox FG. Production and functional roles of nitric oxide in the proximal tubule. Am J Physiol Regul Integr Comp Physiol. 2000;278(5):R1117-24.

10. Neiva LBM, Fonseca CD, Watanabe M, Vattimo MFF. Polymyxin $B$ : dose and time dependent nephrotoxicity effect in vitro. Acta Paul Enferm. 2013;26(1):57-62.

11. Perzynski AT. Multidisciplinary approaches to biomedical research. JAMA. 2010; 304(20):2243-4.

12. Azevedo VF. Medicina translacional: qual a importância para prática reumatológica? Rev Bras Reumatol. 2009;49(1):81-3.

13. Cárnio EC. Basic sciences and nursing. Rev Latino Am Enferm. 2011;19(5):1061-2.
14. Mostardeiro MM, Pereira CA, Marra AR, Pestana JO, Camargo LF. Nephrotoxicity and efficacy assessment of polymyxin use in 92 transplant patients. Antimicrob Agents Chemother. 2013;57(3):1442-6.

15. Solomon R. The role of osmolality in the incidence of contrastinduced nephropathy: A systematic review of angiographic contrast media in high risk patients. Kidney Int. 2005;68(5):2256-64.

16. Ali B. Limiting the damage from acute kidney injury. Nursing. 2011;41(3):22-31.

17. Wood SP. Contrast-induced nephropathy in critical care. Crit Care Nurse. 2012; 32(6):15-23.

18. Chertow GM, Buedick E, Honour M, Bonventre JV, Bates DW. Acute kidney injury, mortality, length of stay, and costs in hospitalized patients. J Am Soc Nephrol. 2005;16(11):3365-70.

19. Bittencourt GKGD, Crossetti MGO. Critical thinking skills in the nursing diagnosis process. Rev Esc Enferm USP [Internet]. 2013 [cited 2013 Nov 16];47(2):341-7. Available from: http://www.scielo.br/pdf/reeusp/v47n2/en_10.pdf

20. Fontes CMB, Cruz DALM. Diagnósticos de enfermagem documentados para pacientes de clínica médica. Rev Esc Enferm USP. 2007; 41(3):395-402.

21. Bagshaw SM, Lapinsky S, Dial S, Arabi Y, Dodek P, Wood G, et al. Acute kidney injury in septic shock: clinical outcomes and impact of duration of hypotension prior to initiation of antimicrobial therapy. Intensive Care Med. 2009;35(5):871-81.

22. Traub SJ, Kellum JA, Tang A, Cataldo L, Kancharla A, Shapiro NI. Risk factors for radiocontrast nephropathy after emergency department contrast-enhanced computerized tomography. Acad Emerg Med. 2013;20(1):40-5.

23. Mendes CAC, Burdmann EA. Polimixinas: revisão em ênfase na sua nefrotoxicidade. Rev Assoc Med Bras. 2009;55(6):752-9. 